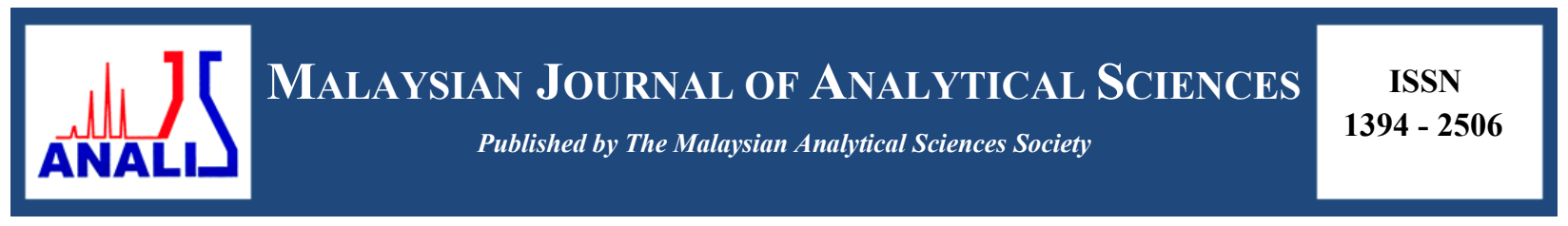

\title{
MICROWAVE-ASSISTED EXTRACTION OF PHENOLIC COMPOUND FROM PINEAPPLE SKINS: THE OPTIMUM OPERATING CONDITION AND COMPARISON WITH SOXHLET EXTRACTION
}

\author{
(Pengekstrakan Sebatian Fenolik daripada Kulit Nenas dengan Bantuan Gelombang Mikro: \\ Pengoptimuman Keadaan Pengendalian dan Perbandingan dengan Pengekstrakan Soxhlet) \\ Nor Halaliza Alias ${ }^{1 *}$ and Zulkifly Abbas $^{2}$ \\ ${ }^{I}$ Faculty of Chemical Engineering, \\ Universiti Teknologi MARA, 40450 Shah Alam, Selangor, Malaysia \\ ${ }^{2}$ Department of Physics, Faculty of Science, \\ Universiti Putra Malaysia, 43400 Serdang, Selangor, Malaysia \\ *Corresponding author: norhalaliza@salam.uitm.edu.my
}

Received: 28 November 2016; Accepted: 5 February 2017

\begin{abstract}
A new method of extraction by using a microwave has been widely used in the extracting of bioactive compound from plants. In this research, the pineapple (Ananas comosus L., Merr) wastes (namely skin) has been chosen as it contains a very high phenolic compound and provide a good source of antioxidant to human's health. The three parameters varied were the microwave power, the types of solvent extraction and the extraction temperature. Each of the samples was evaluated for the Total Phenolic Compound (TPC) and Antioxidant Activity (AA). The aims of this study are to obtain the optimum operating condition of Microwave-Assisted Extraction (MAE) in the extraction of phenolic compound from pineapple skins and to compare the extraction yield between MAE and Soxhlet Extraction (SE) method. From the results, it was found that the optimum condition was at $750 \mathrm{~W}$ microwave power, $60{ }^{\circ} \mathrm{C}$ operating temperature and with the solvent ratio of ethanol: water (50-50) by volume. At this optimum condition, the TPC observed was $207.72 \mathrm{mg} \mathrm{GAE} / \mathrm{g} \mathrm{dw}$, whereas for the $\mathrm{EC}_{50}$, DPPH value obtained was the lowest, $13.2 \mathrm{mg} / \mathrm{mL}$. MAE has proven that this method is comparable to SE, with the TPC obtained was $28.78 \mathrm{mg} \mathrm{GAE} / \mathrm{g} \mathrm{dw}$ and $\mathrm{EC}_{50}$ of $2.78 \mathrm{mg} / \mathrm{L}$, respectively.
\end{abstract}

Keywords: pineapple skin, microwave-assisted extraction, microwave power, total phenolic compound, antioxidant activity

\begin{abstract}
Abstrak
Satu kaedah baru pengekstrakan dengan menggunakan gelombang mikro telah digunakan secara meluas di dalam pengekstrakan sebatian bioaktif daripada tumbuhan. Di dalam kajian ini, sisa (kulit) nenas (Ananas comosus L., Merr) telah dipilih kerana ia mengandungi sebatian fenolik yang tinggi dan menyediakan sumber antioksidan yang baik kepada kesihatan manusia. Tiga parameter boleh ubah iaitu kuasa gelombang mikro, jenis pelarut pengekstrakan dan suhu pengekstrakan. Setiap sampel telah dinilai untuk jumlah sebatian fenolik (TPC) dan aktiviti antioksidan (AA). Tujuan kajian ini adalah untuk mendapatkan keadaan pengendalian optimum oleh bantuan gelombang mikro (MAE) di dalam pengekstrakan sebatian fenolik daripada sisa nenas dan membandingkan hasil pengekstrakan di antara MAE dan pengekstrakan Soxhlet (SE). Daripada keputusan, telah didapati bahawa keadaan optimum adalah pada kuasa gelombang mikro $750 \mathrm{~W}$, pengendalian suhu $60{ }^{\circ} \mathrm{C}$ dan nisbah pelarut etanol: air (50-50) mengikut isipadu. Pada keadaan optimum ini, TPC yang dicerap adalah $207.72 \mathrm{mg} \mathrm{GAE} / \mathrm{g} \mathrm{dw}$, manakala untuk EC 50 , DPPH telah didapati pada nilai yang paling rendah, iaitu $13.2 \mathrm{mg} / \mathrm{mL}$. MAE telah membuktikan bahawa kaedah ini setanding dengan $\mathrm{SE}$, dengan TPC diperoleh adalah masing - masing $28.78 \mathrm{mg} \mathrm{GAE} / \mathrm{g}$ dw dengan $\mathrm{EC}_{50} 2.78 \mathrm{mg} / \mathrm{L}$.
\end{abstract}

Kata kunci: kulit nenas, gelombang mikro terbantu, kuasa gelombang mikro, jumlah sebatian berfenol, aktiviti antioksidan 


\section{Nor Halaliza et al: MICROWAVE-ASSISTED EXTRACTION OF PHENOLIC COMPOUND FROM PINEAPPLE SKINS: THE OPTIMUM OPERATING CONDITION AND COMPARISON WITH SOXHLET EXTRACTION}

\section{Introduction}

Phytochemicals are the major bioactive compounds which usually available in fruits and vegetables. Usually, the plants phenolics are found in both edible and non-edible parts of the plants and was reported to have multiple biological effects, including antioxidant activity [1]. In the recent years, the phenolics compound, or known as polyphenolics have become one of the interest due to their ability to act as a powerful antioxidant [2]. An antioxidant is a group of compounds which are able to delay or inhibit the oxidation lipids or other biomolecules and hence could prevent or repair the damaged body cells that is oxidized by the oxygen $[3,4]$ and it has beneficial effects on metabolism.

The source of antioxidants can be synthetic or natural based. Due to the adverse effect of the synthetic antioxidant, there is an increasing attention to develop a new approach by using natural antioxidant, which is mostly, comes from fruits and vegetables $[5,6]$. Studies have revealed that daily intake of natural antioxidant will help to reduce the risk of those common diseases such as cancer, cardio and cerebro-vascular diseases [7].

In industry, normally the processing fruits will leave behind a large amount of fruits residue, such as peels, seeds, pulp, bean, rind and skin. The disposal of these fruit wastes can create the pollution problem to the environment [8]. In order to overcome this problem, the recovery of the fruit residues is one of the best alternatives. This is because the output from this recovery could be used in pharmaceutical industry, food and cosmetic [9]. In the past few years, the research on the phenolic compounds and antioxidant activity in fruits residues has been conducted on guava leaves [4], mango seed kernel [10], cantaloupe residue (leaf, stem, skin, seed and flesh) [11], bean [12], peanut skins [13], peels of mangosteen, rambutan and pomegranate [14] and citrus mandarin peels [15] and the residue of Kinnow (seed and peel), Litchi (seed and pericarp), grape seed and banana peel [8].

The pineapple, also known as Ananas comosus L., Merr, by-products is not exempted because it consists of peels, stem, pulp and leaves as it's residual. As one of the most important fruits in the world, the pineapple is the leading edible member of the Bromeliacea's family [16]. It contains a good nutrient which gives benefit to human's health. This is because the pineapple contains a very high amount of phenolics compound $[6,16-20]$. Several studies have been conducted in the extracting of phenolic compound from pineapple with different methods such as by using Soxhlet extraction unit $[8,21]$, magnetic stirrer $[6,19,22]$ and orbital shaker (incubator shaker) [20].

In the recent technology of extraction, the microwave-assisted extraction (MAE) has been introduced. As compared to the conventional method, namely Soxhlet extraction unit, the MAE has a lot of advantages in the extraction process such as higher extraction rate, less extraction time, less solvent needed and can produce better product with lower cost [23]. This extraction method has been done on Berberis asiatica leaves [24], chokeberries (Aronia melanocarpa) [25], bark extracts [26], asparagus, cauliflower, celery, and chicory wastes [27], longan peel [28], bean [29], citrus mandarin peel [30], peanut skin [31] and many more.

This research is the extension research which has been done before where the pineapple wastes (namely skin) has been extracted for the analysis of phenolic compounds and antioxidant activity [17]. In this preliminary research, the parameters varied were only the temperature of extraction and the type of solvent used in the extraction, whereas the microwave power has been fixed at $250 \mathrm{~W}$. From this research, it was found that the optimum condition at $250 \mathrm{~W}$ of microwave power was at $30^{\circ} \mathrm{C}$ by using the deionized water as the extraction solvent, with the optimum value of phenolic compound and antioxidant activity $\left(\mathrm{EC}_{50}\right)$ were $206.46 \mathrm{mg} \mathrm{GAE} / \mathrm{g} \mathrm{dw}$ and $13.65 \mathrm{mg} / \mathrm{mL}$, respectively. It indicated that the higher the phenolic value, the lower the $\mathrm{EC}_{50}$, the better the antioxidant property. Thus, it was proven that the pineapple could serve as the potential candidate in becoming one of the best natural antioxidant [17]. However, based on the previous study the microwave power was just fixed at one value only, which was at $250 \mathrm{~W}$. Thus, the effect of the variation in the usage microwave power has not been studied. Therefore, in this research, the microwave power will be varied, as well as the extraction temperature and the types of solvent used. The outcome of this result should reveal the optimum condition of MAE in the extracting of pineapple wastes and the results will be compared with the Soxhlet Extraction Method. 


\section{Material}

\section{Materials and Methods}

The skin of the pineapple (waste) was peeled for the sample preparation [17].

\section{Sample preparation}

The samples (skin) obtained were washed, frozen, dried and grounded. Each sample was weight at $5 \mathrm{~g}$ each before the extraction process [17].

\section{Microwave-assisted extraction}

The extraction process was conducted at three different parameters, namely, the microwave power $(500 \mathrm{~W}, 750 \mathrm{~W}$ and $1000 \mathrm{~W})$, temperature $\left(30{ }^{\circ} \mathrm{C}, 60{ }^{\circ} \mathrm{C}\right.$ and $\left.90{ }^{\circ} \mathrm{C}\right)$ and the type of solvent used $(100 \%$ ethanol, $50 \%$ ethanol in deionized water and $100 \%$ deionized water). About $1 \mathrm{~mL}$ of sample was mixed with $50 \mathrm{~mL}$ of solvent. The extraction time was 20 minutes. The extract obtained was then analyzed for total phenolic compound and antioxidant activity [17].

\section{Total phenolic compound}

The total phenolic compound was measured using the Folin-Ciocalteu method [32]. The results were expressed in milligram of Gallic Acid Equivalent (GAE)/gram of dry weight sample of pineapple (mg GAE/g dw). All samples were analyzed in duplicates [17].

\section{Scavenging activity on DPPH radical}

The scavenging activity or antioxidant activity of the extract was analyzed by 2,2 '-diphenyl-1-picrylhydrazyl radical (DPPH) $[33,34,35]$. All tests were performed in duplicates [17].

\section{Sample statistical analysis}

All the experiments were conducted in duplicates and the mean was calculated using MS Excel [17].

\section{Soxhlet extraction}

A total volume of solvent $250 \mathrm{~mL}(50 \mathrm{~mL}$ of ethanol in $200 \mathrm{~mL}$ of deionized water) was used in the Soxhlet experiment. The solvent was mixed with $5 \mathrm{~g}$ of sample and refluxed for 5 hours at $78{ }^{\circ} \mathrm{C}$. After the extraction process, the supernatant was separated from the solvent by using the rotary evaporator for 15 minutes. The supernatant was then tested for total phenolic content and scavenging activity on DPPH radical analysis.

\section{Effect of microwave power}

\section{Results and Discussion}

The MAE is the process whereby the polar solvent which in contact with the solid samples is heated by using microwave energy [36], thus reducing the extraction time and amount of solvent consumed. The mechanism of MAE in the extracting of phenolic compound can be explained by a phenomenon. In the extraction process, the dried plant used normally will contain small traces of moisture. When the microwave energy is absorbed, this energy will be change to heat and thus the moisture starting to evaporate. This evaporated water will cause the pressure to increase inside the cell wall and lead to the rupture of the cell in the sample. Eventually, the active compound will be released from the rupture cell into the surrounding solvent and increasing the extraction yield [37].

In this research, there were three effects that have been studied. The first effect or parameter was the microwave power used in the extraction. The values were ranged from $250 \mathrm{~W}$ to $1000 \mathrm{~W}$. For each of the microwave power value, the total phenolic compound and antioxidant activity of the pineapple waste were evaluated. Based on the previous research, a standard calibration curve was prepared to get the value of phenolic compound. The graph showed a linear relationship, whereby the gallic acid were ranged from $50-500 \mathrm{mg} / \mathrm{L}$, with a correlation coefficient $\left(\mathrm{R}^{2}\right)$ of $0.97[17]$.

From the preliminary study, the optimum condition at $250 \mathrm{~W}$ microwave power had been obtained at $30{ }^{\circ} \mathrm{C}$ operating temperature by using deionized water as solvent. The study has proven that at $120{ }^{\circ} \mathrm{C}$ operating 


\section{Nor Halaliza et al: MICROWAVE-ASSISTED EXTRACTION OF PHENOLIC COMPOUND FROM PINEAPPLE SKINS: THE OPTIMUM OPERATING CONDITION AND COMPARISON WITH SOXHLET EXTRACTION}

temperature, both phenolic compound and $\mathrm{EC}_{50}$ (defined as the concentration of antioxidant required for $50 \%$ scavenging of DPPH radicals, is a parameter widely used to measure antioxidant activity value from antioxidant activity) marked a deteriorated value [17]. Therefore, in this study the temperatures were varied from $30{ }^{\circ} \mathrm{C}$ to $90{ }^{\circ} \mathrm{C}$ only.

Table 1 showed the extraction condition at $500 \mathrm{~W}$ microwave power. At $30^{\circ} \mathrm{C}$ operating temperature by using ethanol as the solvent, the phenolic compound was $165 \mathrm{mg} \mathrm{GAE} / \mathrm{g} \mathrm{dw}$, whereas the antioxidant value, which reported as $\mathrm{EC}_{50}$, the value was $21.68 \mathrm{mg} / \mathrm{mL}$. Meanwhile, by using the deionized water at $30{ }^{\circ} \mathrm{C}$ operating temperature, the phenolic compound increased to $177.24 \mathrm{mg} \mathrm{GAE} / \mathrm{g} \mathrm{dw}$. The $\mathrm{EC}_{50}$ value at this condition was 15.07 $\mathrm{mg} / \mathrm{mL}$. As the temperature increased to $60^{\circ} \mathrm{C}$, there was a remarkable increase for the phenolic compound, 200.63 $\mathrm{mg} \mathrm{GAE} / \mathrm{g} \mathrm{dw}$ and a sharply decrease for $\mathrm{EC}_{50}$ value, $14.59 \mathrm{mg} / \mathrm{mL}$. The solvent used was ethanol in deionized water (50-50). At the highest operating temperature, which was at $90{ }^{\circ} \mathrm{C}$ the phenolic compound and $\mathrm{EC}_{50}$ recorded were $184.56 \mathrm{mg} \mathrm{GAE} / \mathrm{g} \mathrm{dw}$ and $14.84 \mathrm{mg} / \mathrm{mL}$, respectively. The trends showed that as the temperature increase, the phenolic compound increased until $60{ }^{\circ} \mathrm{C}$ but then decrease at $90{ }^{\circ} \mathrm{C}$. This was contradicting with the trends in $\mathrm{EC}_{50}$, whereby as the temperature increase, the $\mathrm{EC}_{50}$ dropped at $60{ }^{\circ} \mathrm{C}$ but then inclined to $90{ }^{\circ} \mathrm{C}$. From $500 \mathrm{~W}$ microwave power, the optimum value was obtained at $60^{\circ} \mathrm{C}$ by using ethanol in deionized water (50-50). The phenolic compound and $\mathrm{EC}_{50}$ value recorded at this condition were $200.63 \mathrm{mg} \mathrm{GAE} / \mathrm{g} \mathrm{dw}$ and $14.59 \mathrm{mg} / \mathrm{mL}$, respectively. $\mathrm{EC}_{50}$ value is a parameter to measure the antioxidant activity. It is also known as the concentration of antioxidant required for $50 \%$ scavenging of $\mathrm{DPPH}$ radicals. The smaller value of $\mathrm{EC}_{50}$, the higher antioxidant activity of the plant extracts [38]. Therefore, the higher the phenolic compound, the lower the $\mathrm{EC}_{50}$ value, the better the antioxidant property of the pineapple skins.

Table 1. Total phenolic compound and DPPH radical scavenging of the extract at the microwave power of $500 \mathrm{~W}$ with different temperatures and solvents

\begin{tabular}{llcc}
\hline $\begin{array}{l}\text { Temperature } \\
\left({ }^{\circ} \mathbf{C}\right)\end{array}$ & Types of Solvent & $\begin{array}{c}\text { Phenolic Compound } \\
(\mathbf{m g ~ G A E} / \mathbf{g ~ d w})\end{array}$ & $\begin{array}{c}\mathbf{E C}_{\mathbf{5 0}} \\
(\mathbf{m g} / \mathbf{m L})\end{array}$ \\
\hline 30 & Ethanol & 165.23 & 21.68 \\
30 & Water & 177.24 & 15.07 \\
60 & Ethanol-Water $(50-50)$ & 200.63 & 14.59 \\
90 & Ethanol-Water $(50-50)$ & 184.56 & 14.84 \\
\hline
\end{tabular}

The extraction at $750 \mathrm{~W}$ microwave power was shown in Table 2. As compared to the operating microwave power at $500 \mathrm{~W}$, generally the readings of phenolic compound at $750 \mathrm{~W}$ were much higher. The phenolic compound recorded at $30{ }^{\circ} \mathrm{C}$ using ethanol as solvent was $186.25 \mathrm{mg} \mathrm{GAE} / \mathrm{g} \mathrm{dw}$ and the $\mathrm{EC}_{50}$ value obtained was 16.51 $\mathrm{mg} / \mathrm{mL}$. Similar trends go to the operating temperature of $30^{\circ} \mathrm{C}$ using deionized water, the phenolic compound was higher compared to the solvent with pure ethanol. In general, the phenolic compound at $30^{\circ} \mathrm{C}$ operating temperature using deionized water was higher both in $250 \mathrm{~W}$ and $500 \mathrm{~W}$ microwave power. Meanwhile, by using the ethanol in deionized water as a solvent, the phenolic compound at $60{ }^{\circ} \mathrm{C}$ and $90^{\circ} \mathrm{C}$ were $207.72 \mathrm{mg} \mathrm{GAE} / \mathrm{g} \mathrm{dw}$ and $182.34 \mathrm{mg}$ $\mathrm{GAE} / \mathrm{g} \mathrm{dw}$, respectively. The value of $\mathrm{EC}_{50}$ was recorded at $13.2 \mathrm{mg} / \mathrm{mL}$ for $60{ }^{\circ} \mathrm{C}$ operating temperature. At $90{ }^{\circ} \mathrm{C}$, the $\mathrm{EC}_{50}$ was a slightly higher at $14.38 \mathrm{mg} / \mathrm{mL}$. Thus, the optimum condition at $750 \mathrm{~W}$ was at $60{ }^{\circ} \mathrm{C}$ by using ethanol in deionized water.

On the other hand, Table 3 showed the total phenolic compound and $\mathrm{EC}_{50}$ value at $1000 \mathrm{~W}$ microwave power of extraction. Overall, the readings of phenolic compound at $1000 \mathrm{~W}$ microwave power were slightly decreased as compared to $750 \mathrm{~W}$. At $30{ }^{\circ} \mathrm{C}$ operating temperature, the phenolic compound and $\mathrm{EC}_{50}$ value were recorded at $165.54 \mathrm{mg} \mathrm{GAE} / \mathrm{g} \mathrm{dw}$ and $84.03 \mathrm{mg} / \mathrm{mL}$, respectively. Those values were analysed by using ethanol as the solvent. Meanwhile, at $60{ }^{\circ} \mathrm{C}$ operating temperature by using deionized water as the solvent, there was a small inclined in the phenolic compound reading, $187.74 \mathrm{mg} \mathrm{GAE} / \mathrm{g} \mathrm{dw}$. The $\mathrm{EC}_{50}$ value for the antioxidant activity was recorded at $16.41 \mathrm{mg} / \mathrm{mL}$. There were a tremendous decreased in the phenolic compound value for both at $60{ }^{\circ} \mathrm{C}$ and $90{ }^{\circ} \mathrm{C}$ 
operating temperature, which recorded at $163.32 \mathrm{mg} \mathrm{GAE} / \mathrm{g} \mathrm{dw}$ and $79.8 \mathrm{mg} \mathrm{GAE} / \mathrm{g} \mathrm{dw}$, respectively. The same pattern of depreciation could be observed in the $\mathrm{EC}_{50}$ value which depicted at $22.15 \mathrm{mg} / \mathrm{mL}$ and $65.96 \mathrm{mg} / \mathrm{mL}$ for $60{ }^{\circ} \mathrm{C}$ and $90{ }^{\circ} \mathrm{C}$ operating temperature, respectively. The optimum value at $1000 \mathrm{~W}$ microwave power was obtained at $30^{\circ} \mathrm{C}$ operating temperature by using deionized water as solvent.

Table 2. Total phenolic compound and DPPH radical scavenging of the extract at the microwave power of $750 \mathrm{~W}$ with different temperatures and solvents

\begin{tabular}{llcc}
\hline $\begin{array}{l}\text { Temperature } \\
\left({ }^{\circ} \mathbf{C}\right)\end{array}$ & Types of Solvent & $\begin{array}{c}\text { Phenolic Compound } \\
(\mathbf{m g ~ G A E} / \mathbf{g ~ d w})\end{array}$ & $\begin{array}{c}\mathbf{E C}_{\mathbf{5 0}} \\
(\mathbf{m g} / \mathbf{m L})\end{array}$ \\
\hline 30 & Ethanol & 186.25 & 16.51 \\
30 & Water & 195.68 & 15.02 \\
60 & Ethanol-Water $(50-50)$ & 207.72 & 13.20 \\
90 & Ethanol-Water $(50-50)$ & 182.34 & 14.38 \\
\hline
\end{tabular}

Table 3. Total phenolic compound and DPPH radical scavenging of the extract at the microwave power of $1000 \mathrm{~W}$ with different temperatures and solvents

\begin{tabular}{llcc}
\hline $\begin{array}{l}\text { Temperature } \\
\left({ }^{\circ} \mathbf{C}\right)\end{array}$ & Types of Solvent & $\begin{array}{c}\text { Phenolic Compound } \\
(\mathbf{m g ~ G A E} / \mathbf{g ~ d w})\end{array}$ & $\begin{array}{c}\mathbf{E C}_{\mathbf{5 0}} \\
(\mathbf{m g} / \mathbf{m L})\end{array}$ \\
\hline 30 & Ethanol & 165.54 & 84.03 \\
30 & Water & 187.74 & 16.41 \\
60 & Ethanol-Water $(50-50)$ & 163.32 & 22.15 \\
90 & Ethanol-Water $(50-50)$ & 79.80 & 65.96 \\
\hline
\end{tabular}

In any plant extraction, the extraction yield might be reduced if the high microwave power is applied. This is due to the degradation or decomposes of thermal sensible compound. Generally, as the microwave power increase, the extraction yield will be increase linearly, up to a certain limit, before it starts to decrease or become insignificant [39-42]. Microwave power supplies the heating directly to the sample and will assist the MAE to break down the plant cell so that the active compound (analyte) could diffuse from the plant and dissolve in the solvent [43].

From the four-optimized microwave power that have been discussed above based on the reading of phenolic compound and $\mathrm{EC}_{50}$ value, the most optimum microwave power was determined at $750 \mathrm{~W}$. The operating temperature was at $60{ }^{\circ} \mathrm{C}$ and ethanol in deionized water was used as the solvent. At this optimum condition, the highest value of phenolic compound was recorded at $207.72 \mathrm{mg} \mathrm{GAE} / \mathrm{g} \mathrm{dw}$, wheareas the antioxidant activity, $\mathrm{EC}_{50}$ value was obtained at the lowest value of $13.20 \mathrm{mg} / \mathrm{mL}$.

\section{Effect of operating temperature}

The second effect observed in this study was the effect of the extraction temperature. The value of temperature was ranged from $30{ }^{\circ} \mathrm{C}$ up to $90{ }^{\circ} \mathrm{C}$ for all the samples. The temperature and microwave power are interconnected. This is because as the temperature increases, the solvent power will be increases as well due to the decreasing in viscosity and surface tension [37]. However, there will be always a limit of the operating temperature for all the plants and fruits tested before the phenolic compound starts to degrade. A report has claimed that at a very high microwave power such as $1000 \mathrm{~W}$, the extraction yield of the flavonoids from Radix astragali roots has been decreased if the extraction temperature was higher than $110^{\circ} \mathrm{C}$ [40]. Another investigation found that the phenolic compound extracted from Oolong tea has been increased with the increasing extraction temperature and the optimum temperature was obtained at $170{ }^{\circ} \mathrm{C}[44]$. 


\section{Nor Halaliza et al: MICROWAVE-ASSISTED EXTRACTION OF PHENOLIC COMPOUND FROM PINEAPPLE SKINS: THE OPTIMUM OPERATING CONDITION AND COMPARISON WITH SOXHLET EXTRACTION}

According to our preliminary research, the reading of the phenolic compound was increased with the increasing temperature, but slightly decreased at $90{ }^{\circ} \mathrm{C}$ and declined sharply at $120^{\circ} \mathrm{C}$ due to the thermal degradation $[17,43]$. Since the extraction at $120^{\circ} \mathrm{C}$ has proven to be the worst among all the temperatures tested, therefore in this research the focus of temperatures was between $30{ }^{\circ} \mathrm{C}$ to $90{ }^{\circ} \mathrm{C}$. In general, the trends in operating temperature were the same for all the microwave power tested. This is proved by the result from Table 1, 2 and 3. Nevertheless, out of all the operating temperature, the value of the antioxidant activity, $\mathrm{EC}_{50}$ showed the highest value at $30^{\circ} \mathrm{C}$ by using ethanol as the extraction solvent for all microwave power. This showed that the condition was not suitable to extract the phenolic compound from the pineapple skins. Therefore, the most suitable temperature to extract the phenolic compounds from the pineapple wastes was at $60{ }^{\circ} \mathrm{C}$ at $750 \mathrm{~W}$ microwave power.

\section{Effect of solvent extraction}

Among the most commonly used solvent for the extraction of phenolics compound from fresh fruits or plants at different concentration in water are such as ethanol, methanol, ethyl acetate, propanol, acetone and dimethylformamide $[45,46]$. The percentage of polyphenolic yield produced from plant materials is depending on the solubility of the phenolic compounds in the solvent used for the extraction. In other words, the solvent types used in the extraction process is very important as well as its polarity [22]. For example, in the extraction of phenolic compounds from grape skin and seed, methanol has been used as the solvent and it has been proven that the yield of polyphenolic was higher as compared to ethanol, but the latter extract had stronger antioxidant properties [47]. Generally, ethanol is the most common solvent used and acts as a good microwave absorber to extract the bioactive compounds from plants [48]. Based on the result, by referring to the all powers and temperatures shown in Table 1,2 and 3, the highest yield of phenolic compounds was obtained by using ethanol in deionized water as the solvent, at $750 \mathrm{~W}$ microwave power and $60{ }^{\circ} \mathrm{C}$ of operating temperature. The $\mathrm{EC}_{50}$ value recorded was also the lowest at this condition. A study has been reported that by addition of water to the solvent has increased the yield [49]. Several organic solvents should be prepared in the aqueous solution form before it is used as a solvent extraction. This is because with the presence of water in the organic solvent, it can improve the penetration of the solvent into the plant cell and hence, could increase the heating efficiency [50].

\section{Comparison between microwave-assisted extraction method and the soxhlet extraction method}

From the study of the three effects that have been discussed, the optimum condition for microwave power, operating temperature and solvent extraction were $750 \mathrm{~W}, 60^{\circ} \mathrm{C}$ and ethanol in deionized water, respectively. This condition was then compared with the conventional method, namely Soxhlet extraction, by using the ethanol in deionized water as a solvent. The time taken for the Soxhlet extraction was 2 hours [51], whereas for the MAE needed only 20 minutes of extraction time.

Based on Figure 1, there was a significant different in phenolic compound value by using Soxhlet extraction, which was recorded at $28.78 \mathrm{mg} \mathrm{GAE} / \mathrm{g} \mathrm{dw}$ as compared to the MAE [51]. The results of phenolic compound are comparable since the value obtained by using the MAE was much higher at $207.72 \mathrm{mg} \mathrm{GAE} / \mathrm{g} \mathrm{dw}$. On the other hand, Figure 2 shows that the value for $\mathrm{EC}_{50}$ for Soxhlet extraction was lower, $2.78 \mathrm{mg} / \mathrm{mL}$ compared to 13.20 $\mathrm{mg} / \mathrm{mL}$ by using MAE. As discussed in the previous section, the lower the $\mathrm{EC}_{50}$, the greater the antioxidant activity. Even though the $\mathrm{EC}_{50}$ value of Soxhlet extraction is lower compared to MAE, but based on the value of phenolic compound obtained, it has proven that MAE is an effective method compared to Soxhlet extraction. This is in line with the advantages of MAE which only consumed less solvent and has shorter extraction time [52]. Higher extraction rate in fruits, vegetables, foods and beans have been reported in several studies by using MAE compared to the Soxhlet extraction $[53,54,55]$. Lower yield, high amount of solvent used and continuous operation time of 6 or 12 hours make the Soxhlet is not the best extraction method. The long operating hours will lead to the increasing of the operational cost [56]. 


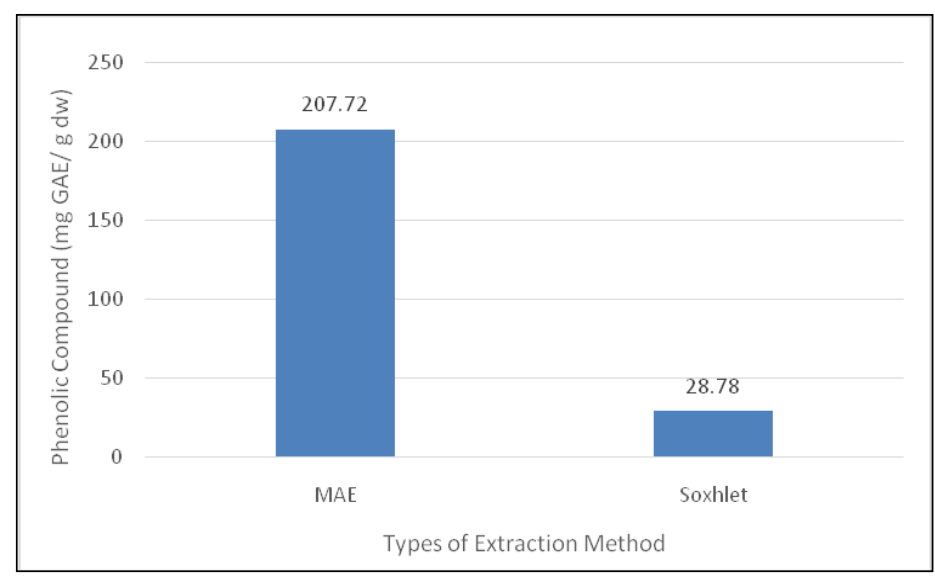

Figure 1. Comparison of total phenolic compound extracted using microwave-assisted extraction and soxhlet method

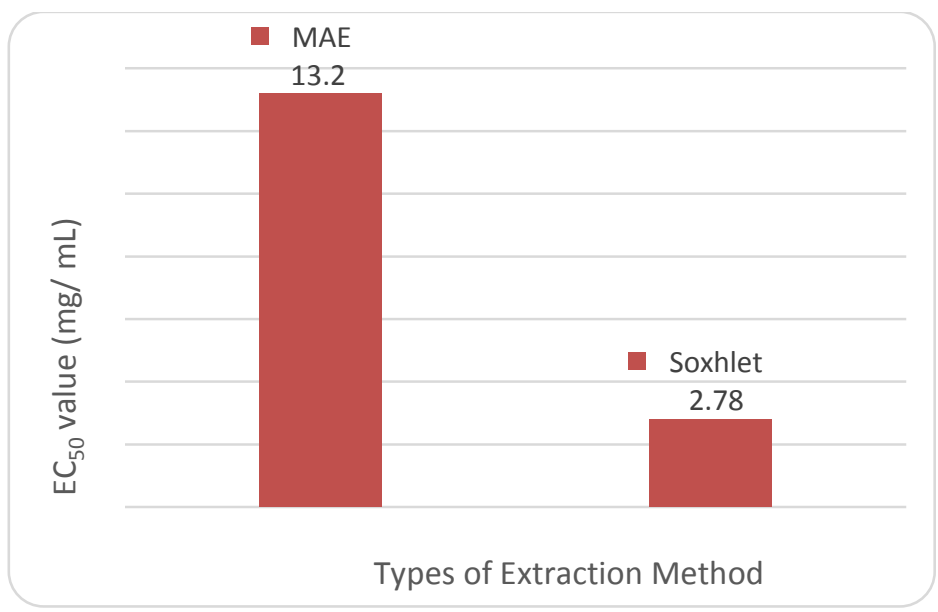

Figure 2. Comparison of DPPH radical scavenging value using microwave-assisted extraction and soxhlet method

\section{Conclusion}

Microwave-assisted extraction (MAE) is an alternative technique of extraction which provides higher yield, shorter time and less solvent used. In this research, three parameters were varied, namely, the microwave power, extraction temperature and solvent type. Based on the results, the optimum condition has been achieved at $750 \mathrm{~W}$ of microwave power, $60{ }^{\circ} \mathrm{C}$ of operating temperature and ethanol in deionized water was used as the solvent. At this optimum condition, the phenolic compound was obtained at the highest yield, which was $207.72 \mathrm{mg} \mathrm{GAE} / \mathrm{g} \mathrm{dw}$, whereas the antioxidant activity or $\mathrm{EC}_{50}$ value was at the lowest, $13.2 \mathrm{mg} / \mathrm{mL}$. The higher the phenolic compound, the lower the $\mathrm{EC}_{50}$ value, the better the antioxidant properties of the fruits or plants. Thus, the pineapple skins could become one of the good sources of antioxidant, which are renewable and environmental friendly compared to the commercial antioxidant. As compared to the Soxhlet extraction method, MAE exhibits more efficient method with a higher extraction of phenolic compound value.

\section{Acknowledgement}

The author would like to acknowledge the financial supports from the Research Management Institute (RMI) Universiti Teknologi MARA, Shah Alam (600-RMI/ST/DANA 5/3/Dst (301/2011) and Faculty of Chemical 


\section{Nor Halaliza et al: MICROWAVE-ASSISTED EXTRACTION OF PHENOLIC COMPOUND FROM PINEAPPLE SKINS: THE OPTIMUM OPERATING CONDITION AND COMPARISON WITH SOXHLET EXTRACTION}

Engineering, Universiti Teknologi MARA, Shah Alam. A special thanks to the Faculty of Science, Universiti Putra Malaysia and Faculty of Chemical Engineering, Universiti Teknologi MARA, Shah Alam for the assistance of laboratory staffs in this project.

\section{References}

1. Cook, N. C. and Sammon S. (1996). Flavanoids chemistry, metabolism, cardioprotective effects and dietary sources. Nutritional Biochemistry, 7: $66-76$.

2. Karakaya, S., El, S. and Ta, A. A. (2001). Antioxidant activity of some foods containing phenolic compounds. International Journal of Food Sciences and Nutrition, 52: $501-508$.

3. Shahidi, F. and Naczk, M. (2004). Phenolics in food and nutraceuticals. CRC Press, Boca Raton, FL.

4. Tachakittirungrod, S., Okonogi, S. and Chowwanapoonpohn, S. (2007). Study on antioxidant activity of certain plants in Thailand: mechanism of antioxidant action of guava leave extract. Journal of Food Chemistry, 103(2): $381-388$.

5. Frankel, E. N. (2007). Antioxidant in food and biology: Facts and fiction. USA: The Oily.

6. Amzad Hossain, M. and Mizanur Rahman, S. M. (2011). Total phenolics, flavanoids and antioxidant activity of tropical fruit pineapple. Journal of Food Research International, 44: 672 - 676.

7. Renaud, S. C., Gueguen, R., Schenker, J. and d'Houtaud, A. (1998). Alcohol and mortality in middle-aged men from France. Epidemiology, 9: 184 - 188.

8. Neha, B., Harinder Singh, O., Dewinder Singh, U. and Ramabhau Patil, P. (2011). Total phenolic compound and antioxidant capacity of extracts obtained from six important fruit residues. Journal of Food Research International, 44: 391 - 396.

9. Makris, D. P., Boskou, G. and Androkopoulus, N. K. (2007). Recovery of antioxidant phenolics from white vinification solid by-products employing water/ethanol mixtures. Bioresource Technology, 98: 2963 - 2967.

10. Maisuthisakul, P. and Gordon, M. H. (2009). Antioxidant and tyrosinase inhibitory activity of mango seed kernel by-product. Journal of Food Chemistry, 117: 332 - 341.

11. Hajar, I. I., Wei Chan, K., Abdalbasit, A. M. and Maznah, I. (2010). Phenolic compound and antioxidant activity of cantaloupe (Cucumis melo) methanolic extract. Journal of Food Chemistry, 119: 643 - 647.

12. Sutivisedsak, N., Cheng, H. N., Willett, J. L., Lesch, W. C., Tangsrud, R. R. and Atanu, B. (2010). Microwaveassisted extraction of phenolics from bean (Phaseolus vulgaris, L.). Journal of Food Research International, 43: $516-519$.

13. Tameshia, S. B., Parameswarakumar, M., Kequan, Z. and Sean, O. (2010). Microwave-assisted extraction of phenolic antioxidant compounds from peanut skin. Journal of Food Chemistry, 120: 1185 - 1192.

14. Okonogi, S., Duangrat, C., Anuchpreeda, S., Tachakittirungrod, S. and Chowwanapoonpohn, S. (2007). Comparison of antioxidant capacities and cytotoxicities of certain fruit peels. Journal of Food Chemistry, 103: $839-846$.

15. Khizar, H., Sarfraz, H., Shabbar, A., Umar, F., Baomiao, D., Shuqin, X., Chengsheng, J., Xiaoming, Z. and Wenshui, X. (2009). Optimized microwave-assisted extraction of phenolic acids from citrus mandarin peels and evaluation of antioxidant activity in vitro. Journal of Separation and Purification Technology, 70: 63 - 70.

16. Atul, U., Jeewan, P. L. and Shinkichi, T. (2010). Utilization of pineapple waste: A review. Review in Journal of Food Science, 6: $10-18$.

17. Alias, N. H. and Zulkifly, A. (2013). Preliminary investigation on the total phenolic compound and antioxidant activity of pineapple wastes via microwave-assisted extraction at fixed microwave power. IEEE Symposium on Business, Engineering and Industrial Application: pp. 423 - 427.

18. Kongsuwan, A., Suthiluk, P., Theppa korn, T., Srilaong, V. and Setha, S. (2009). Bioactive compounds and antioxidant capacities of Phulae and Nanglae pineapple. Asian Journal of Food and Agro-Industry, Special Issue: $44-50$.

19. Adhikarimayum, H., Kshetrimayum, G. and Maibam, D. (2010). Evaluation of antioxidant properties of phenolics extracted from Ananas comosus 1. notulae scientia niologicae. Academic Press: pp. 68 -71.

20. Anynda, Y. and Lee-Fong, S. (2014). A comparative study of the antioxidant properties of three pineapples (Ananas comosus L.) varieties. Journal of Food Studies, 3 (1): 40 - 56.

21. de oliveira, A. C., Valentim, I. B., Silva, C. A., Bechara, E. J. H., de Barros, M. P., Mano, C. M. and Goulart, M. O. F. (2009). Total phenolic compound and free radical scavenging activities of methanolic extract powders of tropical fruit residues. Journal of Food Chemistry, 115: 469 - 475. 
22. Alothman, M., Bhat, R. and Karim, A. A. (2009). Antioxidant capacity and phenolic compound of selected tropical fruits from malaysia, extracted with different solvent. Journal of Food Chemistry, 115: 785 - 788.

23. Glanzer, K., Sanglo, A. and Valko, K. (1986). Microwave extraction - a novel sample preparation method for chromatography. Journal of Chromatography, 371: 299 - 306.

24. Belwal, T., Bhatt, I. D., Rawal, R. S. and Pande, V. (2017). Microwave-assisted extraction (MAE) conditions using polynomial design for improving antioxidant phytochemicals in Berberis asiatica Roxb. Ex DC leaves. Journal of Industrial Crops and Products, 95: $393-403$.

25. Simic, V. M., Rajkovic, K. M., Stojicevic, S. S., Velickovic, D. T., Nikolic, N. C., Lazic, M. L. and Karabegovic, I. T. (2016). Optimization of microwave-assisted extraction of total polyphenolic compounds from chokeberries by response surface methodology and artificial neural network. Journal of Separation and Purification Technology, 160: 89 - 97.

26. Bouras, M., Chadni, M., Barba, F. J., Grimi, N., Bals, O. and Vorobiev, E. (2015). Optimization of microwaveassisted extraction of polyphenols from Quercus bark. Journal of Industrial Crops and Products, 77: 590 601.

27. Baiano, A., Bevilacqua, L., Terracone, C., Conto, F. and Del Nobile, M. A. (2014). Single and interactive effects of process variables on microwave-assisted and conventional extractions of antioxidants from vegetable solid wastes. Journal of Food Engineering, 120: 135 - 145.

28. Pan, Y., Wang, K., Huang, S., Wang, H., Mu, X., He, C., Ji, X., Zhang, J. and Huang, F. (2008). Antioxidant activity of microwave-assisted extract of Longan (Dimocarpus Longan Lour.). Journal of Food Chemistry, 106: $1264-1270$.

29. Sutivisedsak, N., Cheng, H.N., Willett, J. L., Lesch, W. C., Tangsrud, R. R. and Biswas, A. (2010). Microwaveassisted extraction of phenolics from bean (Phaseolus vulgaris L.). Journal of Food Research International, 43: $516-519$.

30. Hayat, K., Hussain, S., Abbas, S., Farooq, U., Ding, B., Xia, S., Jia, C., Zhang, X. and Xia, W. (2009). Optimized microwave-assisted extraction of phenolic acids from citrus mandarin peels and evaluation of antioxidant activity in vitro. Journal of Separation and Purification Technology, 70: $63-70$.

31. Ballard, T. S., Mallikarjunan, P., Zhou, K. and O'Keefe, S. (2010). Microwave-assisted extraction of phenolic antioxidant compounds from peanut skins. Journal of Food Chemistry, 120: 1185- 1192.

32. Singleton, V. L., Orthofer, R. and Lamuela-Raventos, R. M. (1999). Analysis of total phenols and other oxidation substrates and antioxidants by means of Folin-Ciocalteu reagent. Methods in Enzymology, 299: 152 178.

33. Brand, W. W., Cuvelier, M. E. and Berset, C. (1995). Use of a free radical method to evaluate antioxidant activity. Lebensmittel-Wissenschaft und Technologie, 20: 25 - 30.

34. Sanchez-Moreno, C., Larrauri, J. A. and Saura-Calixto, F. (1998). A procedure to measure the antiradical efficiency of polyphenols. Journal of Food and Science and Agriculture, 76: 270 - 276.

35. Blois, M. S. (1958). Antioxidant determinations by the use of a stable free radical. Nature, 26: $1199-1200$.

36. Luque de Castro, M. D. and Luque Garcia, J. L. (2002). Acceleration and automation of solid sample treatment. Amsterdam: Elsevier: pp. 218.

37. Mandal, V., Mohan, Y. and Hemalatha, S. (2007). Microwave-assisted extraction - an innovative and promising extraction tool for medicinal plant research. Pharmacognosy Reviews, 1(1): 7 - 18.

38. Maisuthisakul, P., Suttajit, M. and Pongsawatmanit, R. (2007). Assessment of phenolic compound and free radical-scavenging capacity for some Thai indigeneous plants. Journal of Food Chemistry, 72(2): 145 - 171.

39. Mandal, V. and Mandal, S. C. (2010). Design and performance evaluation of a microwave-based low carbon yielding extraction technique for naturally occurring bioactive triterpenoid: Oleanolic acid. Biochemical Engineering Journal, 50(1-2): 63 - 70.

40. Xiao, W., Han, L. and Shi, B. (2008). Microwave-assisted extraction of flavanoids from Radix astragal. Separation and Purification Technology, 62: $614-618$.

41. Chemat, S., Ait-Amar, H., Lagha, A. and Esveld, D. C. (2005). Microwave-assisted extraction kinetics of terpenes from Caraway seeds. Chemical Engineering and Processing: Process Intensification, 44 (12): 1320 1326.

42. Kwon, J. H., Belanger, J. M. R., Pare, J. R. J. and Yaylayan, V. A. (2003). Application of the MicrowaveAssisted Process $\left(\mathrm{MAP}^{\mathrm{TM}}\right.$ ) to the fast extraction of ginseng Saponins. Food Research Institute, 36: 491 - 498. 
Nor Halaliza et al: MICROWAVE-ASSISTED EXTRACTION OF PHENOLIC COMPOUND FROM PINEAPPLE SKINS: THE OPTIMUM OPERATING CONDITION AND COMPARISON WITH SOXHLET EXTRACTION

43. Chung-Hung, C., Rozita, Y., Gek-Cheng, N. and Fabian Wai-Lee, K. (2011). Microwave-assisted extractions of active ingredients from plants. Journal of Chromatography A, 1218: 6213-6225.

44. Tsubaki, S., Sakamoto, M. and Azuma, J. (2010). Microwave-assisted extraction of phenolic compounds from tea residues under autohydrolytic conditions. Journal of Food Chemistry, 123(4): 1255 - 1258.

45. Antolovich, M., Prenzler, P., Robards, K. and Ryan, D. (2000). Sample preparation in the determination of phenolic compounds in fruit. Journal of Analyst, 125: 989 - 1009.

46. Luthria, D. L. and Mukhopadhyay, S. (2005). Influence of sample preparation on assay of phenolic acids from eggplant. Journal of Agriculture and Food Chemistry, 54: 41 - 47.

47. Casazza, A. A., Aliakbarian, B., Mantegna, S., Cravotto, G. and Perego, P. (2010). Extraction of phenolics from Vitis Vinifera wastes using non-conventional techniques. Journal of Food Engineering, 100: 50 - 55.

48. Zhou, H. Y. and Liu, C. Z. (2006). Microwave-assisted extraction of solanesol from tobacco leaves. Journal of Chromatography A, 1129: 135 - 139.

49. Escribano-Bailon, M. T. and Santos-Buelga, C. (2003). Polyphenol extraction from foods. In C. Santos-Buelga and G. Williamson (Eds.). Methods in polyphenol analysis, UK. The Royal Society of Chemistry: pp. $1-16$.

50. Alfaro, M. J., Belanger, J. M. R., Padilla, F. C. and Pare, J. R. J. (2004). Influence of solvent, matrix dielectric properties and applied power on the liquid-phase microwave-assisted processes $\left(\mathrm{MAP}^{\mathrm{TM}}\right)$ extraction of ginger (Zingiber officinale). Journal of Food Research International, 36(5): 499 - 504.

51. Hatam, S. F., Suryanto, E. and Abidjulu, J. (2013). Aktivitas antioksidan dari ekstrak kulit nenas (Ananas comosus (L) Merr). Pharmacon, Jurnal Ilmiah Farmasi, 2(1): 2310 - 2315.

52. Zhou, T., Xiao, X. H., Wang, J. Y., Chen, J. L., Zhu, X. F., He, Z. F. and Li, G. K. (2012). Evaluation of microwave-assisted extraction for aristolochic acid from aristolochiae fructus by chromatographic analysis coupled with nephrotoxicity studies. Journal of Biomedical Chromatography, 26: 166 - 171.

53. Diange, R. G., Foster, G. D. and Khan, S. U. (2002). Comparison of soxhlet and microwave-assisted extraction for the determination of fenitrothion residues in beans. Journal of Agriculture and Food Chemistry, 50: $3204-$ 3207.

54. Pan, X., Niu, G. and Liu, H. (2003). Microwave-assisted extraction of tea-polyphenols and tea caffeine from green tea leaves. Journal of Chemical Engineering Process, 42: 129 - 133.

55. Singh, S. B., Foster, G. D. and Khan, S. U. (2004). Microwave-assisted extraction for the simultaneous determination of thiamethoxam, imidacloprid and carbendazim residues in fresh and cooked vegetable samples. Journal of Agriculture and Food Chemistry, 52: 105 - 109.

56. Setiawan, C., Purnomo, H. and Kusnadi, J. (2013). Application of microwave-assisted extraction on teak (Tectona grandis) leaves antioxidant extraction. Research Journal of Pharmaceutical, Biological and Chemical Sciences, 4(3): 1012 - 1018. 